\title{
New Strategies for the Next Generation of Matrix-Metalloproteinase Inhibitors: Selectively Targeting Membrane-Anchored MMPs with Therapeutic Antibodies
}

\author{
Laetitia Devy' ${ }^{1}$ and Daniel T. Dransfield ${ }^{2}$ \\ ${ }^{1}$ Merck Serono S.A., 9 Chemin des Mines, Case postale 54, 1211 Geneva 20, Switzerland \\ ${ }^{2}$ Cell Biology and Translational Research, Dyax Corp., 300 Technology Square, Cambridge, MA 02139, USA \\ Correspondence should be addressed to Daniel T. Dransfield, ddransfield@dyax.com
}

Received 27 May 2010; Accepted 4 September 2010

Academic Editor: David N. Brindley

Copyright ( $) 2011$ L. Devy and D. T. Dransfield. This is an open access article distributed under the Creative Commons Attribution License, which permits unrestricted use, distribution, and reproduction in any medium, provided the original work is properly cited.

\begin{abstract}
MMP intervention strategies have met with limited clinical success due to severe toxicities. In particular, treatment with broadspectrum MMP-inhibitors (MMPIs) caused musculoskeletal pain and inflammation. Selectivity may be essential for realizing the clinical potential of MMPIs. Here we review discoveries pinpointing membrane-bound MMPs as mediators of mechanisms underlying cancer and inflammation and as possible therapeutic targets for prevention/treatment of these diseases. We discuss strategies to target these therapeutic proteases using highly selective inhibitory agents (i.e., human blocking antibodies) against individual membrane-bound MMPs.
\end{abstract}

\section{Introduction}

Matrix metalloproteinases (MMPs) are zinc-dependent endopeptidases belonging to a larger family of proteases known as the metzincin superfamily. MMPs play an important role in tumor progression and invasion of inflammatory cells by degrading the extracellular matrix (ECM). Among all MMPs, six (MMP-14, -15, -16, -17, -24, and -25) are referred to as membrane anchored-MMPs (MT-MMPs) [1]. MMP-23 known as CA-MMP (Cysteine array matrix metalloproteinase) is also a membrane-bound MMP but is anchored to the membrane via an $\mathrm{N}$-terminal signal peptide and is structurally distinct from all other MMPs $[2,3]$. This paper will outline the new strategies to select highly selective drugs using monoclonal antibodies. A special emphasis will be put on the properties of membrane-bound MMPs and the scientific basis which makes pursuing them attractive as therapeutic targets in cancer and inflammation.

\section{MMP-Inhibitors in the Clinic}

Except AZD1236 which is currently being developed by AstraZeneca for potential treatment of chronic obstructive pulmonary disease (COPD) and CTS-1027 from Conatus Pharmaceuticals currently being evaluated in a phase II clinical trial in combination with pegylated interferon (Pegasys) and ribavirin (Copegus) in refractory hepatitis C patients, there are currently no synthetic or biologic MMPIs in clinical trials for cancer or arthritis. This is mostly due to the failure of early studies with compounds containing zincchelating groups, such as hydroxamates [4-6]. A tetracycline derivative, doxycycline, in subantimicrobial doses (Periostat; CollaGenex Pharmaceuticals Inc., Newtown, PA, USA) is currently the only MMPI approved by the US FDA and is used as an adjunct therapy in adult periodontitis [7]. The use of tetracyclines for the treatment of arthritic diseases is limited, although doxycycline has been shown to improve some disease parameters as well as reducing the levels 
of collagenase activity in some patients with rheumatoid arthritis (RA) $[8,9]$. Topical doxycycline is also used to enhance healing of chronic wounds [10].

\section{Drawbacks of Broad-Spectrum MMP-Inhibitors}

Numerous studies in different preclinical cancer models demonstrate the ability of hydroxamate-based MMPIs to delay primary tumor growth and block metastasis [11-13]. Unfortunately, these MMP intervention strategies have met with limited clinical success and severe toxicities $[1,14,15]$. Most of the MMPIs eventually demonstrated side effects after short-term dosing (e.g., marimastat) or prolonged treatment (e.g., BMS-275291) related to musculoskeletal pain and inflammation $[16,17]$. The mechanism of these toxicities is widely assumed to be due to the poor selectivity of these compounds [18] but this has not been confirmed. In addition, it is now recognized that among MMPs, some possess cancer-promoting activities while others tumorinhibiting functions [19] underlining the risk of using broad-spectrum MMPIs. Along these lines, in vivo studies have demonstrated that broad-spectrum MMPIs promote metastasis of breast carcinomas as well as lymphomas to the liver in mice $[20,21]$. The upregulation of proangiogenic factors observed in the livers of mice treated with such inhibitors supported a direct effect on the angiogenic process [22]. Alternatively, the broad spectrum MMPIs might also inhibit proteases whose activity generates angiostatic factors. A pyrimidine-2,4,6-trione derivative, belonging to the class of orally-available selective MMPI for MMP-2, -9 , and -14 was not associated with the occurrence of adverse side effects that might reduce the therapeutic potential of these drugs [23] demonstrating the importance of drug selectivity.

\section{Antibody-Based Therapeutic Agents}

Successful therapeutic intervention may critically depend on potently inhibiting one or more MMPs that contribute to disease progression while not inhibiting related MMPs that may be beneficial to the host or if inhibited lead to clinical toxicities. For example, increased expression of MMP-12 by colon carcinoma cells is associated with increased survival [24], and MMP-8 deficient male mice display increased skin cancer susceptibility [25] due to an increased inflammation which delays wound healing [26]. Antibody-based biotherapeutic agents (e.g., human antibodies from phage display libraries) may fulfill this need as they may offer the desired selectivity and potency required for disease-modifying activity [27]. The high affinity binding of a monoclonal antibody to its target confers the potential for high potency and selectivity coupled to a drug scaffold with excellent pharmacological properties. Combining our human antibody phage display library with automated selection and screening strategies (Figure 1) [28], we have identified highly selective antibody-based MMP inhibitor of MMP-14 (DX-2400). DX-2400 displays antih-invasive, antitumor, and antiangiogenic properties and blocks
proMMP-2 processing [29]. HT-1080 cells, which express MMP-14 and MMP-2, were used to assess the effect on MMP-2 activity by the selective inhibition of endogenous MMP-14 by DX-2400. DX-2400 blocked proMMP-2 processing, whereas a polyclonal rabbit anti-MMP-14 antibody, which does not inhibit MMP-14 activity, failed to inhibit proMMP-2 activation. DX-2400 inhibited HUVEC tube formation $\left(\mathrm{IC}_{50} \sim 6 \mathrm{nmol} / \mathrm{L}\right)$ and inhibited migration of HUVECs in a fibrin gel bead assay whereas proliferation was unaffected. DX-2400 also inhibited VEGF165-induced invasion of HUVECs. Our in vivo studies demonstrated that DX-2400 markedly affected tumor growth of human breast cancer (MDA-MB-231) xenograft tumors when used as a single agent or in combination with bevacizumab. Combination therapy with antiangiogenic and novel antiproteolytic agents such as DX-2400 represents a promising approach that may produce a synergistic antitumor effect and a survival benefit for patients. In the MDA-MB-231 model, the antitumor effect of DX-2400 was associated with a strong decrease in tumor vascularization. DX-2400 treatment also induced a significant reduction of MMP activity, supporting an antiproteolytic effect of this antibody. DX-2400 showed in vivo activity at all dosing schedules tested, with every other day treatment regimen yielding the highest efficacy. DX-2400 showed activity against the HER2-positive BT-474 xenografts when used as a single agent or in combination with paclitaxel. These results make DX-2400 an attractive candidate for breast cancer patients, especially in cases where hormonal therapy and/or therapy with Herceptin (trastuzumab) is not effective. DX-2400 combined with bevacizumab resulted in increased tumor growth delay in vivo. DX-2400 did not alter the growth of MCF-7 (MMP-14 negative) derived tumors, showing MMP-14 dependency for DX-2400 action. In addition to its effects on primary tumor growth, DX-2400 also significantly reduced the number of metastatic foci in the MDA-MB-231 orthotopic model and in the i.v. mouse B16F1 melanoma model. Our findings pharmacologically validate the role of MMP-14 in oncology and emphasize the therapeutic potential of specific antibody-based MMP inhibitors such as DX-2400 for the treatment of solid tumors.

Extending our approach to human blocking antibodies targeted against other MMPs will allow for a clear delineation of their role in various pathophysiological diseases and potentially serve as therapeutic agents in cancer and inflammatory diseases.

\section{Properties of Membrane-Anchored MMP: Structure, Regulation, and Tissue Localization}

The primary structure of membrane-anchored MMPs consists of all the domains characteristic of other MMPs (Figure 2), except for MMP-23 which does not contain the hemopexin domains [2]. In addition, MMP-14, $-15,-16$, and -24 are type I transmembrane proteins [30] with a short cytoplasmic tail at the C-terminus [31]. MMP-17 and 
(a) Depletion

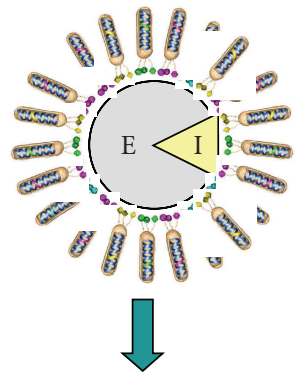

(b) Selection

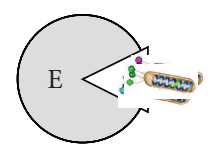

E: enzyme (MMP catalytic domain); I: inhibitor (e.g. timp-2); S: substrate (c) Elution
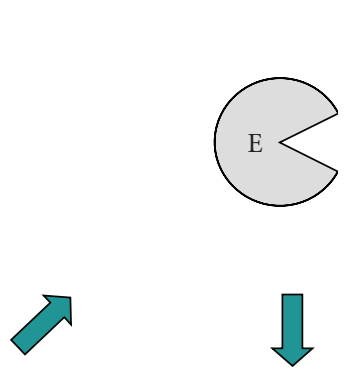

(d) Screening

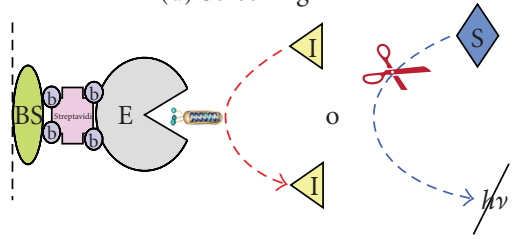

FIgURE 1: MMP inhibitor selection strategy.
Step 1: Phage

library is depleted of phage binding enzyme inhibitor complex

Step 2: Phages that did not bind to enzyme/ inhibitor complex are then incubated with active enzyme

Step 3: Phages

bound to the active site of the enzyme are eluted with excess inhibitor

Step 4: Both enzymatic activity and inhibitor binding assays are used to identify inhibitors
-25 are glycosylphosphatidylinositol- (GPI-) anchored to the cell surface and have a very short cytoplasmic tail which is removed in the endoplasmic reticulum during incorporation of the GPI anchor [32]. Common to all membrane-bound MMPs is the 11 amino acid insertion with a conserved RRKRRRRR sequence, representing a furin cleavage site, located at the end of the propeptide domain. With the exception of MMP-17 and -25, the membrane-associated MMPs also have an insertion of 8 amino acid residues within the catalytic domain or membrane-type- (MT-) loop [33]. MMP-23 has a unique cysteine-rich, proline-rich and interleukin (IL-1) receptor type II-like domains.

$\mathrm{L}_{(20)}$ GAALSGLCLLSALALL $_{(36)}$ is required for this unique membrane localization as a signal anchor [2]. The C-terminal domain of MMP-23 is considerably shorter than other MMPs and shows no sequence similarity to hemopexin [3].

Each member of the membrane-bound MMP subfamily maps to a distinct chromosome which indicates that chromosomal transposition events have played a major role in the evolutionary diversification of this gene family [61]. MMP14 and MMP- 15 share $82.5 \%$ amino acid sequence homology [62], MMP-14 and MMP-16, 66\% [63], MMP-14, and MMP$17,29 \%$ and MMP- 17 and -25, 77\% [3]. MMP-17 and MMP25 display $39 \%$ and $45 \%$ amino acid identity to MMP- 14 [64], suggesting that GPI- anchored MMPs are structurally and functionally distant from MT-MMPs. Expression of membrane-bound MMPs is differentially controlled at the transcriptional level $[63,65,66]$. The mechanism responsible for membrane-bound MMP activation is mediated intracellularly by furin-like proteases [66]. TIMPs (-1 to -4$)$ inhibit enzyme catalytic activity but also regulate MT-MMP processing and internalization, determining the amount of mature enzyme on the cell surface $[40,67,68]$. GPI-anchored
MMPs can be released from the cells in exosomes and transferred to other cell types in a paracrine manner where they can elicit biological effects [57]. Like secreted MMPs, membrane-bound MMPs can cleave extracellular matrix (ECM) molecules, as well as chemokines, cytokines, and growth factors [40] (Table 1). The limited ECM degrading activity of the GPI-anchored MMPs is in accordance with their reported inability to facilitate invasion of basement membranes [69] and invasion of a fibrin gel in vitro [70]. MMP-17 and MMP-25 possess the ability to cleave nonECM proteins [57]. The hemopexin-like domain of MMP14 and -16 are essential for the cleavage of fibrillar collagens. In addition, membrane-bound MMPs are known to cleave and activate secreted MMPs, first described for the activation of MMP-2 by MMP-14 through interaction with TIMP-2 [30, 71]. MMP-14 also has been shown to activate proMMP13 [72]. MMP-14 and -15 mRNA transcripts are expressed in a number of tissues but are distributed quite differently. MMP-16, - -17, -23, -24, and -25 have a more restricted pattern of expression (Table 2).

\section{Membrane-Anchored MMPs in Cancer}

The process of cancer progression involves the action of multiple proteolytic systems, in which membrane-anchored MMPs play a pivotal role. Their localization at the focal cell surface results in conditions especially suitable for cancer cells to progress and invade the ECM [57]. Membranebound MMPs are expressed not only by cancer cells but also by the surrounding tumor stromal cells. They also play a critical role in the development of the desmoplastic reaction characteristic of cancer tissues such as breast, pancreatic, and lung. Changes in the tumor microenvironment due to the desmoplastic reaction may benefit the tumor by 
TABle 1: Substrates for membrane-bound MMPs.

\begin{tabular}{|c|c|c|c|c|}
\hline & Gene/Name & $M_{r}$ latent & $M_{r}$ active & Substrates \\
\hline \multirow{4}{*}{ Type I transmembrane MMPs } & MMP-14 (MT1-MMP) & 66,000 & 56,000 & $\begin{array}{l}\text { Collagen I, II, III [34, 35], and IV [36-38], Gelatin, } \\
\text { cartilage aggrecan, perlecan, fibronectin, vitronectin, } \\
\text { nidogen, laminin, pro-TNF } \alpha[34,35] \text {; proMMP-2 } \\
\text { [39]; proMMP-13 [40]; Galectin-3; MCP-3 [41]; } \\
\text { SDF [42]; cell surface CD44 [43]; tTG [44]. }\end{array}$ \\
\hline & MMP-15 (MT2-MMP) & 72,000 & 60,000 & $\begin{array}{l}\text { Gelatin; fibronectin; tenascin; nidogen; aggrecan; } \\
\text { perlecan and laminin [35]; tTG [44]; proTNF } \alpha \text { [35]; } \\
\text { LRP (CD91) [45]; CXCL12 [46]; proMMP-2 [47]. }\end{array}$ \\
\hline & MMP-16 (MT3-MMP) & 64,000 & 52,000 & $\begin{array}{l}\text { Native Collagen III, } \alpha 2 \text { (I) collagen chain; cartilage } \\
\text { proteoglycan; gelatin; casein; fibronectin; } \\
\text { vitronectin; laminin-1; transferring; } \alpha 1 \text {-proteinase } \\
\text { inhibitor and } \alpha 2 \text {-macroglobulin }[48,49] \text {; tTG [44]; } \\
\text { proMMP-2 [50]. }\end{array}$ \\
\hline & MMP-24 (MT5-MMP) & 63,000 & 45,000 & $\begin{array}{l}\text { Fibronectin; Proteoglycans and cadherins }[51,52] \text {; } \\
\text { Gelatin; proMMP-2 and }-9[53,54] \text {; KISS-1 }[55] \text {. }\end{array}$ \\
\hline \multirow{2}{*}{ GPI-anchored MMPs } & MMP-17 (MT4-MMP) & 57,000 & 53,000 & $\begin{array}{l}\text { Gelatin [56]; alpha2-macroglobulin; ADAMTS-4; } \\
\text { low density lipoprotein receptor related protein [57]; } \\
\text { Fibrin/Fibrinogen; pro-TNF-alpha cleaved by mouse } \\
\text { MMP-17 [58]. }\end{array}$ \\
\hline & MMP-25 (MT6-MMP) & & 56,000 & $\begin{array}{l}\text { Collagen IV; Gelatin; Fibrin/Fibrinogen [59, 60]; } \\
\text { Fibronectin; laminin-1, alpha2-macroglobulin; } \\
\text { ADAMTS-4; Chondroitin and dermatan sulfate } \\
\text { proteoglycan; alpha1 proteinase inhibitor; urokinase } \\
\text { plasminogen activator receptor, Galectin-3 [57]. }\end{array}$ \\
\hline Type II transmembrane MMPs & MMP-23 & 43,900 & $?$ & Unknown. \\
\hline
\end{tabular}

$M_{r}$ : relative molecular mass.

TABLE 2: Expression of membrane-bound MMPs in normal tissues.

\begin{tabular}{|c|c|c|c|}
\hline & Gene/name & cDNA & Expression in normal tissues \\
\hline \multirow{4}{*}{ Type I transmembrane MMPs } & MMP-14 (MT1-MMP) & $\begin{array}{l}\text { Isolated from a human } \\
\text { placenta cDNA library } \\
{[73]}\end{array}$ & $\begin{array}{l}\text { Highly expressed in ossifying tissues and during } \\
\text { mouse embryogenesis, where it is coexpressed with } \\
\text { MMP-2 [74]. Low expression in normal conditions. }\end{array}$ \\
\hline & MMP-15 (MT2-MMP) & $\begin{array}{l}\text { Isolated from a mouse } \\
\text { lung cDNA library [75] }\end{array}$ & $\begin{array}{l}\text { Highly expressed in T cells [76], rat smooth muscle } \\
\text { cells [77], and endothelial cells [78]. Expressed in } \\
\text { hepatocytes and biliary epithelial cells [79], in } \\
\text { cytotrophoblasts [80], in activated NK-cells [81], } \\
\text { and in microglial cells [82]. }\end{array}$ \\
\hline & MMP-16 (MT3-MMP) & $\begin{array}{l}\text { Isolated from placenta } \\
\text { cDNA library [63] }\end{array}$ & $\begin{array}{l}\text { Expressed in human brain tissues (microglial cells) } \\
{[62] \text {; T cells }[76] \text {; endothelial cells }[78,83] \text {; }} \\
\text { Langerhans cells following cell activation }[84]\end{array}$ \\
\hline & MMP-24 (MT5-MMP) & $\begin{array}{l}\text { Isolated from mouse } \\
\text { brain cDNA library [54] }\end{array}$ & $\begin{array}{l}\text { Predominantly expressed in the central nervous } \\
\text { system [85] and in T lymphocytes [76]. }\end{array}$ \\
\hline \multirow{2}{*}{ GPI-anchored MMPs } & MMP-17 (MT4-MMP) & $\begin{array}{l}\text { Isolated from a human } \\
\text { breast carcinoma cDNA } \\
\text { library [66] }\end{array}$ & $\begin{array}{l}\text { Expressed in monocytic cells [86], leukocytes, brain, } \\
\text { ovary, testis, and colon [66].MMP-17 mRNA is } \\
\text { significantly represented in B cells [76]. }\end{array}$ \\
\hline & MMP-25 (MT6-MMP) & $\begin{array}{l}\text { Isolated from peripheral } \\
\text { blood leukocytes [64] }\end{array}$ & $\begin{array}{l}\text { Predominantly expressed in leukocytes [64]. In rats, } \\
\text { mRNA peak expression levels in testis, kidney, and } \\
\text { skeletal muscle [85]. }\end{array}$ \\
\hline Type II transmembrane MMPs & MMP-23 & $\begin{array}{l}\text { Isolated from an ovarian } \\
\text { cDNA library [3] }\end{array}$ & $\begin{array}{l}\text { Abundantly expressed in normal tissues in adults } \\
\text { under quiescent conditions and predominantly } \\
\text { expressed in reproductive tissues and others such as } \\
\text { heart [3]. }\end{array}$ \\
\hline
\end{tabular}


Type I transmembrane-MMPs: MMP-14, $-15,-16$, and -24

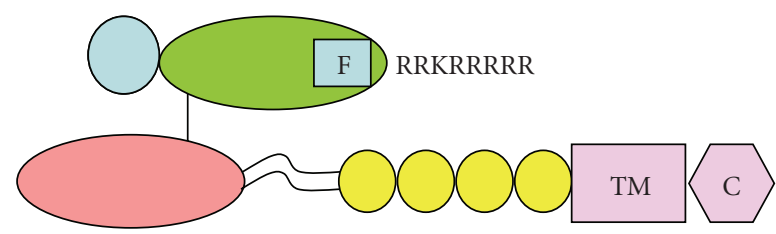

GPI-anchored MMPs: MMP-17 and -25

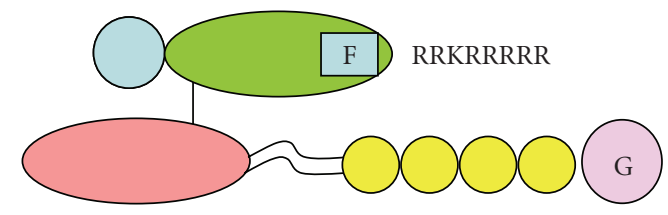

Type II transmembrane-MMP: MMP-23
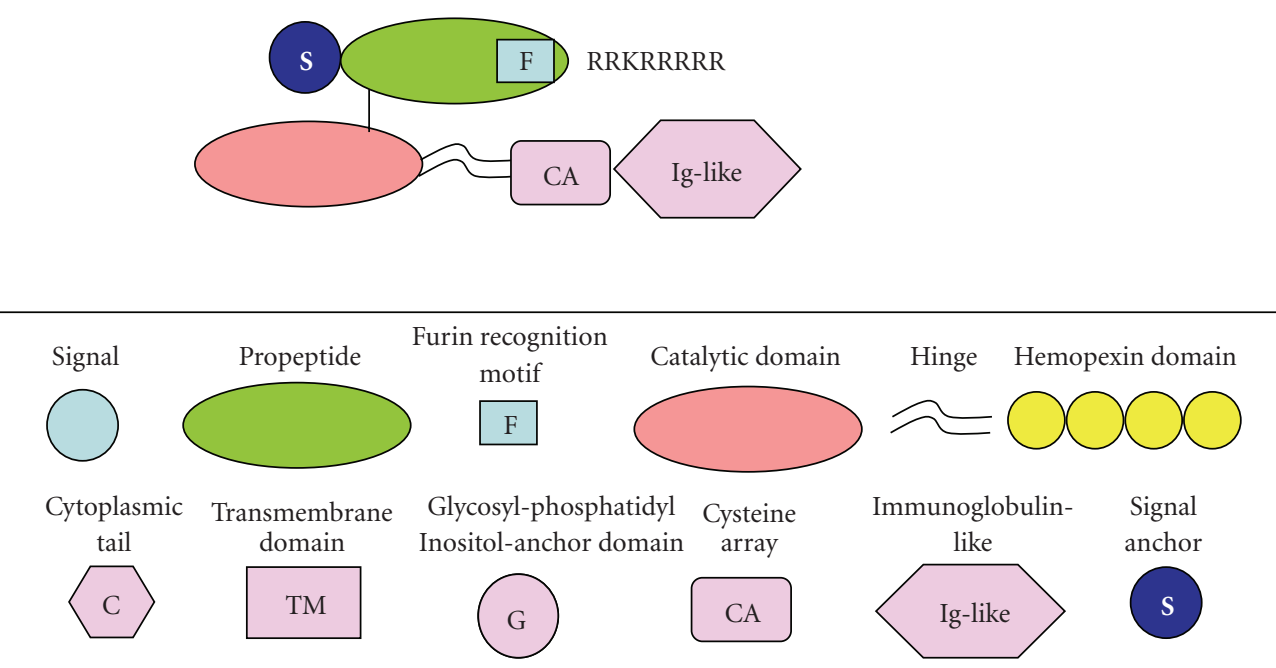

Figure 2: Primary structure of membrane-anchored MMPs.

enhancing proliferation, inducing a more invasive malignant phenotype, and increasing chemoresistance.

6.1. Type I Transmembrane MMPs. Extensive work from the Weiss laboratory demonstrated that select type I membraneanchored MMPs (MMP-14 and MMP-15) function as directacting, proinvasive factors for expansive growth of primary tumors within a tridimensional collagen type I matrix. The proinvasive, angiogenic, and metastatic activities of MMP14 and MMP-15 are unique relative to all other MMP family members and cannot be mimicked in vivo by secreted MMPs, MMP-1, -2, -3, -7, -9, or -13 [87]. MMP-14 drives invasion by functioning as a pericellular collagenase [88], an activator of proMMP-2 [30, 89], and is directly linked to tumorigenesis and metastasis [90-92]. MMP-14 expression is elevated in various human carcinomas including uterine cervix [93], stomach [94], lung [95-97], breast [98], colon
[99], head and neck [100], malignant brain tumors [101], and melanoma [102]. MMP-14 immunostaining in primary tumor specimens is a prognostic predictor in patients with medullary thyroid carcinomas [103] or carcinoma of the larynx [104]. High MMP-14 expression is associated with early death of patients with supraglottic carcinoma [105], colorectal carcinoma [106], or breast cancer [107] and is correlated with lymph node metastases, progression, invasion, poor clinical stage, larger tumor size, and with increasing tumor stage [108, 109]. The expression of MMP14 and MMP-2 correlates with the depth of tumor and vascular invasion in human colon cancer [110].

MMP-15 also plays a key role in cancer progression, tumor invasion, and metastasis [111]. MMP-15 mRNA is expressed in breast carcinoma [112] and pancreatic cancer tissues [113]. Higher levels of MMP-15 are observed in nonsmall cell lung carcinomas (NSCLCs) relative to 
squamous cell carcinoma (SCCs) and normal lung tissues which indicate that MMP-15 may be a viable molecular diagnostic marker for NSCLCs [96]. Chemokine CXCL12 upregulates MMP-15 expression in glioma cells and serves as an effector of CXCR4 signaling in these cells by promoting cell invasion [46]. MMP-15 has antiapoptotic activity [114] and may connect metastasis and resistance to cell death by apoptosis through an unknown regulatory mechanism.

MMP-16 is expressed in human hepatocellular carcinoma and correlates significantly with capsular invasion [110]. MMP-16 is expressed by and promotes invasion of melanoma cells [115].

MMP-24 mRNA is highly expressed in brain tumors, including astrocytomas and glioblastomas [53]. MMP-24 gene silencing by RNAi can suppress the invasiveness of SKOV-3 ovarian cancer cells in vitro, which may provide a new therapeutic approach for this type of cancer [116].

6.2. GPI-Anchored MMPs. GPI-anchored MMPs are associated with progression of human cancer by mechanisms different from the type I transmembrane MMPs. There is an excellent review on the properties and expression of MMP-17 and MMP-25 in cancer published by Sohail and coworkers [57]. Data suggest that GPI-anchored MMPs do not act as progelatinase activators, are mostly non-ECM degrading enzymes, and do not promote cell migration and invasion. MMP-17 promotes primary tumor growth and lung metastasis in preclinical models. MMP-17 is strongly expressed in human breast cancer cells and in metastatic cells in human lymph nodes [117]. Chabottaux et al. applied experimental and spontaneous models of lung metastasis using human breast adenocarcinoma MDA-MB-231 cells overexpressing or not MMP-17 and found that MMP-17 promotes lung metastasis by disturbing the tumor vessel integrity and thereby facilitating tumor cell intravasation [118]. Human MMP-25 is expressed by leukocytes and neutrophils, and in colon, urothelial, brain, and prostate cancers [59, 119-122]. MMP-25 was suggested to contribute to disease progression in gliomas [123]. Expression of MMP-25 in HCT-116 human colon cancer cells promotes tumorigenesis in nude mice. Histologically, the MMP-25expressing tumors demonstrate an infiltrative leading edge. Strong MMP-25 staining was detected in inflammatory-like cells consistent with the known expression of MMP-25 in leukocytes [64].

6.3. Type II Transmembrane MMP. The body of work on MMP-23 in cancer is still very limited when compared to other MMPs. It is interesting to note that the presence of MMP-23 in MDA-MB-231 cells and its involvement in cell invasiveness after gene silencing by RNAi have been reported [124].

\section{Membrane-Anchored MMPs in Inflammatory Diseases}

Inflammatory disease encompasses a huge array of disorders that can be very localized, regional, or systemic. MMPs act on proinflammatory cytokines, chemokines, and other proteins to regulate varied aspects of inflammation and immunity. Numerous targets of MMP activity that directly affect components of the immune system inflammatory pathways have been described in a review by Cauwe et al. [125].

7.1. Type 1-Transmembrane MT-MMPs. Uncontrolled cell migration and tissue invasion are one of the important factors that promote progression of diseases such as RA. In RA, inflamed synovial pannus tissue invades into cartilage and bone, resulting in dysfunctioning joint. Recent results from Itoh's group based on Western blot analysis of primary synovial cells and immunohistochemical analysis of RA joint specimens have highlighted the key role played by MMP-14 in the progression of RA by promoting cartilage invasion by synovial pannus tissue [126]. Jain et al. also showed that invasive potential of human rheumatoid tenosynovial cells is partly MMP-14 dependent [127]. MMP-15, which activates proMMP-2 and proMMP-13 and is involved in TNF $\alpha$ processing (Table 1), also may facilitate inflammatory tissue destruction in RA [128].

Johnson et al. have highlighted MMP-14 as a potential target for the stabilization of atherosclerotic lesions [129]. Furthermore, they also published a study on the effect of a broad spectrum nonselective MMPI in this mouse model in which it was demonstrated that the nonselective MMPI has no beneficial effects on atherosclerosis [130]. Subsequently using double-deficient mice, they observed that with regards to atherosclerotic plaque disruption, some MMPs are beneficial and some are detrimental [131]. MMP24 plays a role in the pathogenesis of renal tubular atrophy and end-stage renal disease [132]. MMP-24-null mice do not develop neuropathic pain induced by peripheral nerve lesions [133].

7.2. GPI-Anchored MMPs. MMP-17 is involved in cartilage destruction by activating ADAMTS-4 [134, 135]. Contrary to the reported role of MMP-17 as a TNF $\alpha$ sheddase [58], the lipopolysaccharide- (LPS-) induced release of TNF $\alpha$ from mmp-17(-/-) macrophages was similar to that in wildtype cells [136]. Using quantitative RT-PCR, Bar-Or and colleagues have systematically analyzed the expression of MMP members in subsets of leukocytes isolated from the blood of normal individuals [76]. MMP-17 is significantly expressed in B cells. A recent study from Shiryaev and colleagues highlights the key role played by MMP-25 in the proteolytic pathway in multiple sclerosis (MS) [137]. MMP-25 is superior to MMP-2, -8, -9, -10, -12, -14, -15, $-16,-17$, and -24 in cleaving myelin basic protein (MBP) isoforms. Proteolysis of the Golli-MBP isoforms by MMP25 followed by the stimulation of the specific autoimmune $\mathrm{T}$ cells causes increased inflammation. This leads to the further upregulation of the activity of multiple MMPs and the massive cleavage of $\mathrm{MBP}$ in the brain resulting in demyelination and MS [137]. MMP-25 is a novel and promising drug target in MS especially when compared with other individual MMPs. 
7.3. Type II Transmembrane MMP. MMP- 23 mRNA is expressed in chondrocytes and osteoblasts, suggesting a role in some aspect of cartilage or bone formation [138]. ADAM-12 and MMP-23 are coexpressed in painful tendinopathy [139] suggesting a role for these in this inflammatory disorder.

\section{Acknowledgment}

The authors would like to thank Dr. Barbara Fingleton (Vanderbilt University School of Medicine) for her careful review of this paper.

\section{References}

[1] S. Zucker, J. Cao, and W.-T. Chen, "Critical appraisal of the use of matrix metalloproteinase inhibitors in cancer treatment," Oncogene, vol. 19, no. 56, pp. 6642-6650, 2000.

[2] D. Pei, T. Kang, and H. Qi, "Cysteine array matrix metalloproteinase (CA-MMP)/MMP-23 is a type II transmembrane matrix metalloproteinase regulated by a single cleavage for both secretion and activation," Journal of Biological Chemistry, vol. 275, no. 43, pp. 33988-33997, 2000.

[3] G. Velasco, A. M. Pendás, A. Fueyo, V. Knäuper, G. Murphy, and C. López-Otín, "Cloning and characterization of human MMP-23, a new matrix metalloproteinase predominantly expressed in reproductive tissues and lacking conserved domains in other family members," Journal of Biological Chemistry, vol. 274, no. 8, pp. 4570-4576, 1999.

[4] N. C. Levitt, F. A. L. M. Eskens, K. J. O’Byrne et al., "Phase I and pharmacological study of the oral matrix metalloproteinase inhibitor, MMI270 (CGS27023A), in patients with advanced solid cancer," Clinical Cancer Research, vol. 7, no. 7, pp. 1912-1922, 2001.

[5] M. C. Noe, V. Natarajan, S. L. Snow et al., "Discovery of 3,3dimethyl-5-hydroxypipecolic hydroxamate-based inhibitors of aggrecanase and MMP-13," Bioorganic and Medicinal Chemistry Letters, vol. 15, no. 11, pp. 2808-2811, 2005.

[6] H.-G. Lombart, E. Feyfant, D. Joseph-McCarthy et al., "Design and synthesis of 3,3-piperidine hydroxamate analogs as selective TACE inhibitors," Bioorganic and Medicinal Chemistry Letters, vol. 17, no. 15, pp. 4333-4337, 2007.

[7] B. Pirard, "Insight into the structural determinants for selective inhibition of matrix metalloproteinases," Drug Discovery Today, vol. 12, no. 15-16, pp. 640-646, 2007.

[8] D. Nordström, O. Lindy, A. Lauhio, T. Sorsa, S. Santavirta, and Y. T. Konttinen, "Anti-collagenolytic mechanism of action of doxycycline treatment in rheumatoid arthritis," Rheumatology International, vol. 17, no. 5, pp. 175-180, 1998.

[9] J. R. O'Dell, "Is there a role for antibiotics in the treatment of patients with rheumatoid arthritis?" Drugs, vol. 57, no. 3, pp. 279-282, 1999.

[10] J. Stechmiller, L. Cowan, and G. Schultz, "The role of doxycycline as a matrix metalloproteinase inhibitor for the treatment of chronic wounds," Biological Research for Nursing, vol. 11, no. 4, pp. 336-344, 2010.

[11] R. G. S. Chirivi, A. Garofalo, M. J. Crimmin et al., "Inhibition of the metastatic spread and growth of B16-BL6 murine melanoma by a synthetic matrix metalloproteinase inhibitor," International Journal of Cancer, vol. 58, no. 3, pp. 460-464, 1994.

[12] M. Hidalgo and S. G. Eckhardt, "Development of matrix metalloproteinase inhibitors in cancer therapy," Journal of the National Cancer Institute, vol. 93, no. 3, pp. 178-193, 2001.
[13] M. Bloomston, E. E. Zervos, and A. S. Rosemurgy II, "Matrix metalloproteinases and their role in pancreatic cancer: a review of preclinical studies and clinical trials," Annals of Surgical Oncology, vol. 9, no. 7, pp. 668-674, 2002.

[14] L. M. Coussens, B. Fingleton, and L. M. Matrisian, "Matrix metalloproteinase inhibitors and cancer: trials and tribulations," Science, vol. 295, no. 5564, pp. 2387-2392, 2002.

[15] H. Sato, "Tumor metastasis and MMP inhibitor," Clinical Calcium, vol. 16, no. 4, pp. 621-626, 2006.

[16] A. H. Drummond, P. Beckett, P. D. Brown et al., "Preclinical and clinical studies of MMP inhibitors in cancer," Annals of the New York Academy of Sciences, vol. 878, pp. 228-235, 1999.

[17] J. W. Skiles, N. C. Gonnella, and A. Y. Jeng, "The design, structure, and clinical update of small molecular weight matrix metalloproteinase inhibitors," Current Medicinal Chemistry, vol. 11, no. 22, pp. 2911-2977, 2004.

[18] B. Fingleton, "MMPs as therapeutic targets-still a viable option?" Seminars in Cell and Developmental Biology, vol. 19, no. 1, pp. 61-68, 2008.

[19] M. Egeblad and Z. Werb, "New functions for the matrix metalloproteinases in cancer progression," Nature Reviews Cancer, vol. 2, no. 3, pp. 161-174, 2002.

[20] P. Della Porta, R. Soeltl, H.-W. Krell et al., "Combined treatment with serine protease inhibitor aprotinin and matrix metalloproteinase inhibitor Batimastat (BB-94) does not prevent invasion of human esophageal and ovarian carcinoma cells in vivo," Anticancer Research, vol. 19, no. 5B, pp. 3809-3816, 1999.

[21] A. Krüger, R. Soeltl, I. Sopov et al., "Hydroxamate-type matrix metalloproteinase inhibitor batimastat promotes liver metastasis," Cancer Research, vol. 61, no. 4, pp. 1272-1275, 2001.

[22] G. Bergers, R. Brekken, G. McMahon et al., "Matrix metalloproteinase- 9 triggers the angiogenic switch during carcinogenesis," Nature Cell Biology, vol. 2, no. 10, pp. 737$744,2000$.

[23] E. Maquoi, N. E. Sounni, L. Devy et al., "Anti-invasive, antitumoral, and antiangiogenic efficacy of a pyrimidine2,4,6-trione derivative, an orally active and selective matrix metalloproteinases inhibitor," Clinical Cancer Research, vol. 10, no. 12, pp. 4038-4047, 2004.

[24] S. Zucker and J. Vacirca, "Role of matrix metalloproteinases (MMPs) in colorectal cancer," Cancer and Metastasis Reviews, vol. 23, no. 1-2, pp. 101-117, 2004.

[25] M. Balbín, A. Fueyo, A. M. Tester et al., "Loss of collagenase2 confers increased skin tumor susceptibility to male mice," Nature Genetics, vol. 35, no. 3, pp. 252-257, 2003.

[26] A. Gutiérrez-Fernández, M. Inada, M. Balbín et al., "Increased inflammation delays wound healing in mice deficient in collagenase-2 (MMP-8)," FASEB Journal, vol. 21, no. 10, pp. 2580-2591, 2007.

[27] A. E. Nixon and C. R. Wood, "Engineered protein inhibitors of proteases," Current Opinion in Drug Discovery and Development, vol. 9, no. 2, pp. 261-268, 2006.

[28] R. M. Hoet, E. H. Cohen, R. B. Kent et al., "Generation of high-affinity human antibodies by combining donorderived and synthetic complementarity-determining-region diversity," Nature Biotechnology, vol. 23, no. 3, pp. 344-348, 2005.

[29] L. Devy, L. Huang, L. Naa et al., "Selective inhibition of matrix metalloproteinase-14 blocks tumor growth, invasion, and angiogenesis," Cancer Research, vol. 69, no. 4, pp. 15171526, 2009. 
[30] H. Sato, T. Kinoshita, T. Takino, K. Nakayama, and M. Seiki, "Activation of a recombinant membrane type 1-matrix metalloproteinase (MT1-MMP) by furin and its interaction with tissue inhibitor of metalloproteinases (TIMP)-2," FEBS Letters, vol. 393, no. 1, pp. 101-104, 1996.

[31] V. Knäuper, H. Will, C. López-Otin et al., "Cellular mechanisms for human procollagenase-3 (MMP-13) activation. Evidence that MT1-MMP (MMP-14) and gelatinase A (MMP-2) are able to generate active enzyme," Journal of Biological Chemistry, vol. 271, no. 29, pp. 17124-17131, 1996.

[32] S. Udenfriend and K. Kodukula, "How glycosylphosphatidylinositol-anchored membrane proteins are made," Annual Review of Biochemistry, vol. 64, pp. 563-591, 1995.

[33] J. L. English, Z. Kassiri, I. Koskivirta et al., "Individual Timp deficiencies differentially impact pro-MMP-2 activation," Journal of Biological Chemistry, vol. 281, no. 15, pp. 1033710346, 2006.

[34] E. Ohuchi, K. Imai, Y. Fujii, H. Sato, M. Seiki, and Y. Okada, "Membrane type 1 matrix metalloproteinase digests interstitial collagens and other extracellular matrix macromolecules," Journal of Biological Chemistry, vol. 272, no. 4, pp. 2446-2451, 1997.

[35] M.-P. D’Ortho, H. Will, S. Atkinson et al., "Membranetype matrix metalloproteinases 1 and 2 exhibit broadspectrum proteolytic capacities comparable to many matrix metalloproteinases," European Journal of Biochemistry, vol. 250, no. 3, pp. 751-757, 1997.

[36] K. B. Hotary, E. D. Allen, P. C. Brooks, N. S. Datta, M. W. Long, and S. J. Weiss, "Membrane type I matrix metalloproteinase usurps tumor growth control imposed by the three-dimensional extracellular matrix," Cell, vol. 114, no. 1, pp. 33-45, 2003.

[37] W. G. Stetler-Stevenson and A. E. Yu, "Proteases in invasion: matrix metalloproteinases," Seminars in Cancer Biology, vol. 11, no. 2, pp. 143-152, 2001.

[38] K. Wolf, Y. I. Wu, Y. Liu et al., "Multi-step pericellular proteolysis controls the transition from individual to collective cancer cell invasion," Nature Cell Biology, vol. 9, no. 8, pp. 893-904, 2007.

[39] A. Y. Strongin, I. Collier, G. Bannikov, B. L. Marmer, G. A. Grant, and G. I. Goldberg, "Mechanism of cell surface activation of $72-\mathrm{kDa}$ type IV collagenase. Isolation of the activated form of the membrane metalloprotease," Journal of Biological Chemistry, vol. 270, no. 10, pp. 5331-5338, 1995.

[40] S. Hernandez-Barrantes, M. Bernardo, M. Toth, and R. Fridman, "Regulation of membrane type-matrix metalloproteinases," Seminars in Cancer Biology, vol. 12, no. 2, pp. 131138, 2002.

[41] G. A. McQuibban, J.-H. Gong, J. P. Wong, J. L. Wallace, I. Clark-Lewis, and C. M. Overall, "Matrix metalloproteinase processing of monocyte chemoattractant proteins generates CC chemokine receptor antagonists with anti-inflammatory properties in vivo," Blood, vol. 100, no. 4, pp. 1160-1167, 2002.

[42] G. A. McQuibban, G. S. Butler, J.-H. Gong et al., "Matrix metalloproteinase activity inactivates the CXC chemokine stromal cell-derived factor-1," Journal of Biological Chemistry, vol. 276, no. 47, pp. 43503-43508, 2001.

[43] M. Kajita, Y. Itoh, T. Chiba et al., "Membrane-type 1 matrix metalloproteinase cleaves CD44 and promotes cell migration," Journal of Cell Biology, vol. 153, no. 5, pp. 893 904, 2001.
[44] A. M. Belkin, S. S. Akimov, L. S. Zaritskaya, B. I. Ratnikov, E. I. Deryugina, and A. Y. Strongin, "Matrix-dependent proteolysis of surface transglutaminase by membrane-type metalloproteinase regulates cancer cell adhesion and locomotion," Journal of Biological Chemistry, vol. 276, no. 21, pp. 18415-18422, 2001.

[45] D. V. Rozanov, E. Hahn-Dantona, D. K. Strickland, and A. Y. Strongin, "The low density lipoprotein receptor-related protein LRP is regulated by membrane type- 1 matrix metalloproteinase (MT1-MMP) proteolysis in malignant cells," Journal of Biological Chemistry, vol. 279, no. 6, pp. 42604268, 2004.

[46] J. Zhang, S. Sarkar, and V. W. Yong, "The chemokine stromal cell derived factor-1 (CXCL12) promotes glioma invasiveness through MT2-matrix metalloproteinase," Carcinogenesis, vol. 26, no. 12, pp. 2069-2077, 2005.

[47] C. J. Morrison, G. S. Butler, H. F. Bigg, C. R. Roberts, P. D. Soloway, and C. M. Overall, "Cellular activation of MMP-2 (gelatinase A) by MT2-MMP occurs via a TIMP-2independent pathway," Journal of Biological Chemistry, vol. 276, no. 50, pp. 47402-47410, 2001.

[48] S.-I. Matsumoto, M. Katoh, S. Saito, T. Watanabe, and Y. Masuho, "Identification of soluble type of membrane-type matrix metalloproteinase-3 formed by alternatively spliced mRNA," Biochimica et Biophysica Acta, vol. 1354, no. 2, pp. 159-170, 1997.

[49] T. Shimada, H. Nakamura, E. Ohuchi et al., "Characterization of a truncated recombinant form of human membrane type 3 matrix metalloproteinase," European Journal of Biochemistry, vol. 262, no. 3, pp. 907-914, 1999.

[50] H. Zhao, M. M. Bernardo, P. Osenkowski et al., "Differential inhibition of membrane type 3 (MT3)-matrix metalloproteinase (MMP) and MT1-MMP by tissue inhibitor of metalloproteinase (TIMP)-2 and TIMP-3 regulates proMMP-2 activation," Journal of Biological Chemistry, vol. 279, no. 10, pp. 8592-8601, 2004.

[51] X. Wang, J. Yi, J. Lei, and D. Pei, "Expression, purification and charaterization of recombinant mouse MT5-MMP protein products," FEBS Letters, vol. 462, no. 3, pp. 261-266, 1999.

[52] S. Monea, B. A. Jordan, S. Srivastava, S. DeSouza, and E. B. Ziff, "Membrane localization of membrane type 5 matrix metalloproteinase by AMPA receptor binding protein and cleavage of cadherins," Journal of Neuroscience, vol. 26, no. 8, pp. 2300-2312, 2006.

[53] E. Llano, A. M. Pendás, J. P. Freije et al., "Identification and characterization of human MT5-MMP, a new membranebound activator of progelatinase a overexpressed in brain tumors," Cancer Research, vol. 59, no. 11, pp. 2570-2576, 1999.

[54] D. Pei, "Identification and characterization of the fifth membrane-type matrix metalloproteinase MT5-MMP," Journal of Biological Chemistry, vol. 274, no. 13, pp. 8925-8932, 1999.

[55] T. Takino, N. Koshikawa, H. Miyamori et al., "Cleavage of metastasis suppressor gene product KiSS-1 protein/metastin by matrix metalloproteinases," Oncogene, vol. 22, no. 30, pp. 4617-4626, 2003.

[56] H. Kolkenbrock, L. Essers, N. Ulbrich, and H. Will, "Biochemical characterization of the catalytic domain of membrane-type 4 matrix metalloproteinase," Biological Chemistry, vol. 380, no. 9, pp. 1103-1108, 1999.

[57] A. Sohail, Q. Sun, H. Zhao, M. M. Bernardo, J.-A. Cho, and R. Fridman, "MT4-(MMP17) and MT6-MMP (MMP25), 
a unique set of membrane-anchored matrix metalloproteinases: properties and expression in cancer," Cancer and Metastasis Reviews, vol. 27, no. 2, pp. 289-302, 2008.

[58] W. R. English, X. S. Puente, J. M. P. Freije et al., "Membrane type 4 matrix metalloproteinase (MMP17) has tumor necrosis factor- $\alpha$ convertase activity but does not activate proMMP2," Journal of Biological Chemistry, vol. 275, no. 19, pp. 14046-14055, 2000.

[59] T. Kang, J. Yi, A. Guo et al., "Subcellular distribution and cytokine- and chemokine-regulated secretion of leukolysin/MT6-MMP/MMP-25 in neutrophils," Journal of Biological Chemistry, vol. 276, no. 24, pp. 21960-21968, 2001.

[60] W. R. English, G. Velasco, J. O. Stracke, V. Knäuper, and G. Murphy, "Catalytic activities of membrane-type 6 matrix metalloproteinase (MMP25)," FEBS Letters, vol. 491, no. 1-2, pp. 137-142, 2001.

[61] E. Llano, A. M. Pendás, V. Knäuper et al., "Identification and structural and functional characterization of human enamelysin (MMP-20)," Biochemistry, vol. 36, no. 49, pp. 15101-15108, 1997.

[62] Y. Yoshiyama, H. Sato, M. Seiki, A. Shinagawa, M. Takahashi, and T. Yamada, "Expression of the membrane-type 3 matrix metalloproteinase (MT3-MMP) in human brain tissues," Acta Neuropathologica, vol. 96, no. 4, pp. 347-350, 1998.

[63] T. Takino, H. Sato, A. Shinagawa, and M. Seiki, "Identification of the second membrane-type matrix metalloproteinase (MT- MMP-2) gene from a human placenta cDNA library. MT-MMPs form a unique membrane-type subclass in the MMP family," Journal of Biological Chemistry, vol. 270, no. 39, pp. 23013-23020, 1995.

[64] D. Pei, "Leukolysin/MMP25/MT6-MMP: a novel matrix metalloproteinase specifically expressed in the leukocyte lineage," Cell Research, vol. 9, no. 4, pp. 291-303, 1999.

[65] H. Will and B. Hinzmann, "cDNA sequence and mRNA tissue distribution of a novel human matrix metalloproteinase with a potential transmembrane segment," European Journal of Biochemistry, vol. 231, no. 3, pp. 602-608, 1995.

[66] X. S. Puente, A. M. Pendás, E. Llano, G. Velasco, and C. López-Otín, "Molecular cloning of a novel membrane-type matrix metalloproteinase from a human breast carcinoma," Cancer Research, vol. 56, no. 5, pp. 944-949, 1996.

[67] E. Maquoi, F. Frankenne, A. Noël, H.-W. Krell, F. Grams, and J.-M. Foidart, "Type IV collagen induces matrix metalloproteinase 2 activation in HT1080 fibrosarcoma cells," Experimental Cell Research, vol. 261, no. 2, pp. 348-359, 2000.

[68] A. Remacle, G. Murphy, and C. Roghi, "Membrane type Imatrix metalloproteinase (MT1-MMP) is internalised by two different pathways and is recycled to the cell surface," Journal of Cell Science, vol. 116, no. 19, pp. 3905-3916, 2003.

[69] K. Hotary, X.-Y. Li, E. Allen, S. L. Stevens, and S. J. Weiss, "A cancer cell metalloprotease triad regulates the basement membrane transmigration program," Genes and Development, vol. 20, no. 19, pp. 2673-2686, 2006.

[70] K. B. Hotary, I. Yana, F. Sabeh et al., "Matrix metalloproteinases (MMPs) regulate fibrin-invasive activity via MT1MMP-dependent and -independent processes," Journal of Experimental Medicine, vol. 195, no. 3, pp. 295-308, 2002.

[71] A. Mitra, J. Chakrabarti, A. Banerji, and A. Chatterjee, "Cell membrane-associated MT1-MMP dependent activation of MMP-2 in SiHa (human cervical cancer) cells," Journal of Environmental Pathology, Toxicology and Oncology, vol. 25, no. 4, pp. 655-666, 2006.
[72] V. Knäuper, L. Bailey, J. R. Worley, P. Soloway, M. L. Patterson, and G. Murphy, "Cellular activation of proMMP13 by MT1-MMP depends on the C-terminal domain of MMP-13," FEBS Letters, vol. 532, no. 1-2, pp. 127-130, 2002.

[73] T. Takino, H. Sato, A. Shinagawa, and M. Seiki, "Identification of the second membrane-type matrix metalloproteinase (MT- MMP-2) gene from a human placenta cDNA library. MT-MMPs form a unique membrane-type subclass in the MMP family," Journal of Biological Chemistry, vol. 270, no. 39, pp. 23013-23020, 1995.

[74] H. Sato, Y. Okada, and M. Seiki, "Membrane-type matrix metalloproteinases (MT-MMPs) in cell invasion," Thrombosis and Haemostasis, vol. 78, no. 1, pp. 497-500, 1997.

[75] M. Tanaka, H. Sato, T. Takino, K. Iwata, M. Inoue, and M. Seiki, "Isolation of a mouse MT2-MMP gene from a lung cDNA library and identification of its product," FEBS Letters, vol. 402, no. 2-3, pp. 219-222, 1997.

[76] A. Bar-Or, R. K. Nuttall, M. Duddy et al., "Analyses of all matrix metalloproteinase members in leukocytes emphasize monocytes as major inflammatory mediators in multiple sclerosis," Brain, vol. 126, no. 12, pp. 2738-2749, 2003.

[77] K.-I. Shofuda, Y. Nagashima, K. Kawahara, H. Yasumitsu, K. Miki, and K. Miyazaki, "Elevated expression of membranetype 1 and 3 matrix metalloproteinases in rat vascular smooth muscle cells activated by arterial injury," Laboratory Investigation, vol. 78, no. 8, pp. 915-923, 1998.

[78] M. A. Lefleur, M. M. Handsley, V. Knäuper, G. Murphy, and D. R. Edwards, "Endothelial tubulogenesis within fibrin gels specifically requires the activity of membrane-type-matrix metalloproteinases (MT-MMPs)," Journal of Cell Science, vol. 115, no. 17, pp. 3427-3438, 2002.

[79] N. Théret, O. Musso, A. L'Helgoualc'h, J.-P. Campion, and B. Clément, "Differential expression and origin of membranetype 1 and 2 matrix metalloproteinases (MT-MMPS)in association with MMP2 activation in injured human livers," American Journal of Pathology, vol. 153, no. 3, pp. 945-954, 1998.

[80] S. F. Bjørn, N. Hastrup, J. F. Larsen, L. R. Lund, and C. Pyke, "Messenger RNA for membrane-type 2 matrix metalloproteinase, MT2-MMP, is expressed in human placenta of first trimester," Placenta, vol. 21, no. 2-3, pp. 170-176, 2000.

[81] M. H. Kim, P. Albertsson, Y. Xue, R. P. Kitson, U. Nannmark, and R. H. Goldfarb, "Expression of matrix metalloproteinases and their inhibitors by rat NK cells: inhibition of their expression by genistein," In Vivo, vol. 14, no. 5, pp. 557$564,2000$.

[82] H. Toft-Hansen, R. K. Nuttall, D. R. Edwards, and T. Owens, "Key metalloproteinases are expressed by specific cell types in experimental autoimmune encephalomyelitis," Journal of Immunology, vol. 173, no. 8, pp. 5209-5218, 2004.

[83] M. Plaisier, K. Kapiteijn, P. Koolwijk et al., "Involvement of membrane-type matrix metalloproteinases (MT-MMPs) in capillary tube formation by human endometrial microvascular endothelial cells: role of MT3-MMP," Journal of Clinical Endocrinology and Metabolism, vol. 89, no. 11, pp. 58285836, 2004.

[84] N. Noirey, M.-J. Staquet, M.-J. Gariazzo et al., "Relationship between expression of matrix metalloproteinases and migration of epidermal and in vitro generated Langerhans cells," European Journal of Cell Biology, vol. 81, no. 7, pp. 383-389, 2002.

[85] F. Bernal, H.-P. Hartung, and B. C. Kieseier, "Tissue mRNA expression in rat of newly described matrix 
metalloproteinases," Biological Research, vol. 38, no. 2-3, pp. 267-271, 2005.

[86] M. Kajita, H. Kinoh, N. Ito et al., "Human membrane type-4 matrix metalloproteinase (MT4-MMP) is encoded by a novel major transcript: isolation of complementary DNA clones for human and mouse mt4-mmp transcripts," FEBS Letters, vol. 457, no. 3, pp. 353-356, 1999.

[87] I. Ota, X.-Y. Li, Y. Hu, and S. J. Weiss, "Induction of a MT1-MMP and MT2-MMP-dependent basement membrane transmigration program in cancer cells by Snail1," Proceedings of the National Academy of Sciences of the United States of America, vol. 106, no. 48, pp. 20318-20323, 2009.

[88] X.-Y. Li, I. Ota, I. Yana, F. Sabeh, and S. J. Weiss, "Molecular dissection of the structural machinery underlying the tissueinvasive activity of membrane type-1 matrix metalloproteinase," Molecular Biology of the Cell, vol. 19, no. 8, pp. 32213233, 2008.

[89] K. Holmbeck, P. Bianco, J. Caterina et al., "MT1-MMPdeficient mice develop dwarfism, osteopenia, arthritis, and connective tissue disease due to inadequate collagen turnover," Cell, vol. 99, no. 1, pp. 81-92, 1999.

[90] S. Ogura, T. Ohdaira, Y. Hozumi, Y. Omoto, and H. Nagai, "Metastasis-related factors expressed in pT1 pN0 breast cancer: assessment of recurrence risk," Journal of Surgical Oncology, vol. 96, no. 1, pp. 46-53, 2007.

[91] D. V. Rozanov, A. Y. Savinov, R. Williams et al., "Molecular signature of MT1-MMP: transactivation of the downstream universal gene network in cancer," Cancer Research, vol. 68, no. 11, pp. 4086-4096, 2008.

[92] Y. Tsunezuka, H. Kinoh, T. Takino et al., "Expression of membrane-type matrix metalloproteinase 1 (MT1-MMP) in tumor cells enhances pulmonary metastasis in an experimental metastasis assay," Cancer Research, vol. 56, no. 24, pp. 5678-5683, 1996.

[93] C. Gilles, M. Polette, J. Piette et al., "High level of MT-MMP expression is associated with invasiveness of cervical cancer cells," International Journal of Cancer, vol. 65, no. 2, pp. 209 213, 1996.

[94] H. Nomura, H. Sato, M. Seiki, M. Mai, and Y. Okada, "Expression of membrane-type matrix metalloproteinase in human gastric carcinomas," Cancer Research, vol. 55, no. 15, pp. 3263-3266, 1995.

[95] K. Okudera, Y. Kamata, S. Takanashi et al., "Small adenocarcinoma of the lung: prognostic significance of central fibrosis chiefly because of its association with angiogenesis and lymphangiogenesis," Pathology International, vol. 56, no. 9, pp. 494-502, 2006.

[96] J. M. Atkinson, C. J. Pennington, S. W. Martin et al., "Membrane type matrix metalloproteinases (MMPs) show differential expression in non-small cell lung cancer (NSCLC) compared to normal lung: correlation of MMP-14 mRNA expression and proteolytic activity," European Journal of Cancer, vol. 43, no. 11, pp. 1764-1771, 2007.

[97] A. Janowska-Wieczorek, M. Wysoczynski, J. Kijowski et al., "Microvesicles derived from activated platelets induce metastasis and angiogenesis in lung cancer," International Journal of Cancer, vol. 113, no. 5, pp. 752-760, 2005.

[98] C. Gilles, M. Polette, M. Seiki, P. Birembaut, and E. W. Thompson, "Implication of collagen type I-induced membrane-type 1-matrix metalloproteinase expression and matrix metalloproteinase- 2 activation in the metastatic progression of breast carcinoma," Laboratory Investigation, vol. 76, no. 5, pp. 651-660, 1997.
[99] K. Nabeshima, T. Inoue, Y. Shimao et al., "Front-cell-specific expression of membrane-type 1 matrix metalloproteinase and gelatinase A during cohort migration of colon carcinoma cells induced by hepatocyte growth factor/scatter factor," Cancer Research, vol. 60, no. 13, pp. 3364-3369, 2000.

[100] E. L. Rosenthal and L. M. Matrisian, "Matrix metalloproteases in head and neck cancer," Head and Neck, vol. 28, no. 7, pp. 639-648, 2006.

[101] S. Yoshida and H. Takahashi, "Expression of extracellular matrix molecules in brain metastasis," Journal of Surgical Oncology, vol. 100, no. 1, pp. 65-68, 2009.

[102] R. A. Bartolomé, S. Ferreiro, M. E. Miquilena-Colina et al., "The chemokine receptor CXCR4 and the metalloproteinase MT1-MMP are mutually required during melanoma metastasis to lungs," American Journal of Pathology, vol. 174, no. 2, pp. 602-612, 2009.

[103] B. G. Cavalheiro, C. R. Junqueira, and L. G. Brandão, "Expression of membrane type 1 matrix metalloproteinase in medullary thyroid carcinoma: prognostic implications," Head and Neck, vol. 32, no. 1, pp. 58-67, 2010.

[104] K. Starska, O. Stasikowska, M. Łukomski, and I. LewyTrenda, "Correlation of membrane type I matrix metalloproteinase (MT1-MMP) expression with clinicomorphological features of tumor front in squamous cell carcinoma of the larynx," Polski Merkuriusz Lekarski, vol. 23, no. 135, pp. 188191, 2007.

[105] H. Zhang, M. Liu, Y. Sun, and J. Lu, "MMP-14 can serve as a prognostic marker in patients with supraglottic cancer," European Archives of Oto-Rhino-Laryngology, vol. 266, no. 9, pp. 1427-1434, 2009.

[106] R. Bendardaf, H. Lamlum, P. Vihinen, R. Ristamäki, J. Laine, and S. Pyrhönen, "Low collagenase-1 (MMP-1) and MT1MMP expression levels are favourable survival markers in advanced colorectal carcinoma," Oncology, vol. 65, no. 4, pp. 337-346, 2003.

[107] W. G. Jiang, G. Davies, T. A. Martin et al., "Expression of membrane type-1 matrix metalloproteinase, MT1-MMP in human breast cancer and its impact on invasiveness of breast cancer cells," International Journal of Molecular Medicine, vol. 17, no. 4, pp. 583-590, 2006.

[108] B. Têtu, J. Brisson, C. S. Wang et al., "The influence of MMP-14, TIMP-2 and MMP-2 expression on breast cancer prognosis," Breast Cancer Research, vol. 8, no. 3, article R28, 2006.

[109] K. Mimori, H. Ueo, C. Shirasaka, and M. Mori, "Clinical significance of MT1-MMP mRNA expression in breast cancer," Oncology Reports, vol. 8, no. 2, pp. 401-403, 2001.

[110] R. Kikuchi, T. Noguchi, S. Takeno, N. Kubo, and Y. Uchida, "Immunohistochemical detection of membranetype-1-matrix metalloproteinase in colorectal carcinoma," British Journal of Cancer, vol. 83, no. 2, pp. 215-218, 2000.

[111] Y. Ohnishi, S. Tajima, and A. Ishibashi, "Coordinate expression of membrane type-matrix metalloproteinases2 and 3 (MT2-MMP and MT3-MMP) and matrix metalloproteinase-2 (MMP-2) in primary and metastatic melanoma cells," European Journal of Dermatology, vol. 11, no. 5, pp. 420-423, 2001.

[112] H. Ueno, H. Nakamura, M. Inoue et al., "Expression and tissue localization of membrane-types 1,2, and 3 matrix metalloproteinases in human invasive breast carcinomas," Cancer Research, vol. 57, no. 10, pp. 2055-2060, 1997.

[113] V. Ellenrieder, B. Alber, U. Lacher et al., "Role of MT-MMPs and MMP-2 in pancreatic cancer progression," International Journal of Cancer, vol. 85, no. 1, pp. 14-20, 2000. 
[114] R. Abraham, J. Schäfer, M. Rothe, J. Bange, P. Knyazev, and A. Ullrich, "Identification of MMP-15 as an anti-apoptotic factor in cancer cells," Journal of Biological Chemistry, vol. 280, no. 40, pp. 34123-34132, 2005.

[115] J. Iida, D. Pei, T. Kang et al., "Melanoma chondroitin sulfate proteoglycan regulates matrix metalloproteinase-dependent human melanoma invasion into type I collagen," Journal of Biological Chemistry, vol. 276, no. 22, pp. 18786-18794, 2001.

[116] Y. P. Luo, M. Zhong, L. P. Wang, M. Zhong, G. Q. Sun, and J. Li, "Inhibitory effects of RNA interference on MMP-24 expression and invasiveness of ovarian cancer $\operatorname{SKOV(3)~cells,"~}$ Nan Fang Yi Ke Da Xue Xue Bao, vol. 29, no. 4, pp. 781-784, 2009.

[117] V. Chabottaux, N. E. Sounni, C. J. Pennington et al., "Membrane-type 4 matrix metalloproteinase promotes breast cancer growth and metastases," Cancer Research, vol. 66, no. 10, pp. 5165-5172, 2006.

[118] V. Chabottaux, S. Ricaud, L. Host et al., "Membranetype 4 matrix metalloproteinase (MT4-MMP) induces lung metastasis by alteration of primary breast tumour vascular architecture," Journal of Cellular and Molecular Medicine, vol. 13, pp. 4002-4013, 2009.

[119] G. Velasco, S. Cal, A. Merlos-Suárez et al., "Human MT6matrix metalloproteinase: identification, progelatinase A activation, and expression in brain tumors," Cancer Research, vol. 60, no. 4, pp. 877-882, 2000.

[120] Q. Sun, C. R. Weber, A. Sohail et al., "MMP25 (MT6-MMP) is highly expressed in human colon cancer, promotes tumor growth, and exhibits unique biochemical properties," Journal of Biological Chemistry, vol. 282, no. 30, pp. 21998-22010, 2007.

[121] M. J. Wallard, C. J. Pennington, A. Veerakumarasivam et al., "Comprehensive profiling and localisation of the matrix metalloproteinases in urothelial carcinoma," British Journal of Cancer, vol. 94, no. 4, pp. 569-577, 2006.

[122] A. C. P. Riddick, C. J. Shukla, C. J. Pennington et al., "Identification of degradome components associated with prostate cancer progression by expression analysis of human prostatic tissues," British Journal of Cancer, vol. 92, no. 12, pp. 2171-2180, 2005.

[123] R. K. Nuttall, C. J. Pennington, J. Taplin et al., "Elevated membrane-type matrix metalloproteinases in gliomas revealed by profiling proteases and inhibitors in human cancer cells," Molecular Cancer Research, vol. 1, no. 5, pp. 333-345, 2003.

[124] L. Hegedüs, H. Cho, X. Xie, and G. L. Eliceiri, "Additional MDA-MB-231 breast cancer cell matrix metalloproteinases promote invasiveness," Journal of Cellular Physiology, vol. 216, no. 2, pp. 480-485, 2008.

[125] B. Cauwe, P. E. Van den Steen, and G. Opdenakker, "The biochemical, biological, and pathological kaleidoscope of cell surface substrates processed by matrix metalloproteinases," Critical Reviews in Biochemistry and Molecular Biology, vol. 42, no. 3, pp. 113-185, 2007.

[126] M.-C. Miller, H. B. Manning, A. Jain et al., "Membrane type 1 matrix metalloproteinase is a crucial promoter of synovial invasion in human rheumatoid arthritis," Arthritis and Rheumatism, vol. 60, no. 3, pp. 686-697, 2009.

[127] A. Jain, M.-C. Miller, L. Troeberg, Y. Itoh, F. Brennan, and J. Nanchahal, "Invasive potential of human rheumatoid tenosynovial cells is in part MT1-MMP dependent," Journal of Hand Surgery, vol. 34, no. 7, pp. 1282-1290, 2009.

[128] Y. T. Konttinen, M. Ainola, H. Valleala et al., "Analysis of 16 different matrix metalloproteinases (MMP-1 to MMP-20) in the synovial membrane: different profiles in trauma and rheumatoid arthritis," Annals of the Rheumatic Diseases, vol. 58, no. 11, pp. 691-697, 1999.

[129] J. L. Johnson, G. B. Sala-Newby, Y. Ismail, C. M. Aguilera, and A. C. Newby, "Low tissue inhibitor of metalloproteinases 3 and high matrix metalloproteinase 14 levels defines a subpopulation of highly invasive foam-cell macrophages," Arteriosclerosis, Thrombosis, and Vascular Biology, vol. 28, no. 9, pp. 1647-1653, 2008.

[130] J. L. Johnson, R. Fritsche-Danielson, M. Behrendt et al., "Effect of broad-spectrum matrix metalloproteinase inhibition on atherosclerotic plaque stability," Cardiovascular Research, vol. 71, no. 3, pp. 586-595, 2006.

[131] J. L. Johnson, S. J. George, A. C. Newby, and C. L. Jackson, "Divergent effects of matrix metalloproteinases 3, 7, 9, and 12 on atherosclerotic plaque stability in mouse brachiocephalic arteries," Proceedings of the National Academy of Sciences of the United States of America, vol. 102, no. 43, pp. 1557515580, 2005.

[132] A. M. Romanic, C. L. Burns-Kurtis, Z. Ao, A. J. Arleth, and E. H. Ohlstein, "Upregulated expression of human membrane type-5 matrix metalloproteinase in kidneys from diabetic patients," American Journal of Physiology, vol. 281, no. 2, pp. F309-F317, 2001.

[133] K. Komori, T. Nonaka, A. Okada et al., "Absence of mechanical allodynia and $\mathrm{A} \beta$-fiber sprouting after sciatic nerve injury in mice lacking membrane-type 5 matrix metalloproteinase," FEBS Letters, vol. 557, no. 1-3, pp. 125-128, 2004.

[134] G. Gao, A. Plaas, V. P. Thompson, S. Jin, F. Zuo, and J. D. Sandy, "ADAMTS4 (aggrecanase-1) activation on the cell surface involves C-terminal cleavage by glycosylphosphatidyl inositol-anchored membrane type 4-matrix metalloproteinase and binding of the activated proteinase to chondroitin sulfate and heparan sulfate on syndecan-1," Journal of Biological Chemistry, vol. 279, no. 11, pp. 1004210051, 2004.

[135] P. Patwari, G. Gao, J. H. Lee, A. J. Grodzinsky, and J. D. Sandy, "Analysis of ADAMTS4 and MT4-MMP indicates that both are involved in aggrecanolysis in interleukin-1-treated bovine cartilage," Osteoarthritis and Cartilage, vol. 13, no. 4, pp. 269277, 2005.

[136] A. Rikimaru, K. Komori, T. Sakamoto et al., "Establishment of an MT4-MMP-deficient mouse strain representing an efficient tracking system for MT4-MMP/MMP-17 expression in vivo using $\beta$-galactosidase," Genes to Cells, vol. 12, no. 9, pp. 1091-1100, 2007.

[137] S. A. Shiryaev, A. Y. Savinov, P. Cieplak et al., "Matrix metalloproteinase proteolysis of the myelin basic protein isoforms is a source of immunogenic peptides in autoimmune multiple sclerosis," PLoS ONE, vol. 4, no. 3, article e4952, 2009.

[138] B. M. Clancy, J. D. Johnson, A.-J. Lambert et al., "A gene expression profile for endochondral bone formation: oligonucleotide microarrays establish novel connections between known genes and BMP-2-induced bone formation in mouse quadriceps," Bone, vol. 33, no. 1, pp. 46-63, 2003.

[139] G. Riley, "Tendinopathy_from basic science to treatment," Nature Clinical Practice Rheumatology, vol. 4, no. 2, pp. 8289, 2008. 

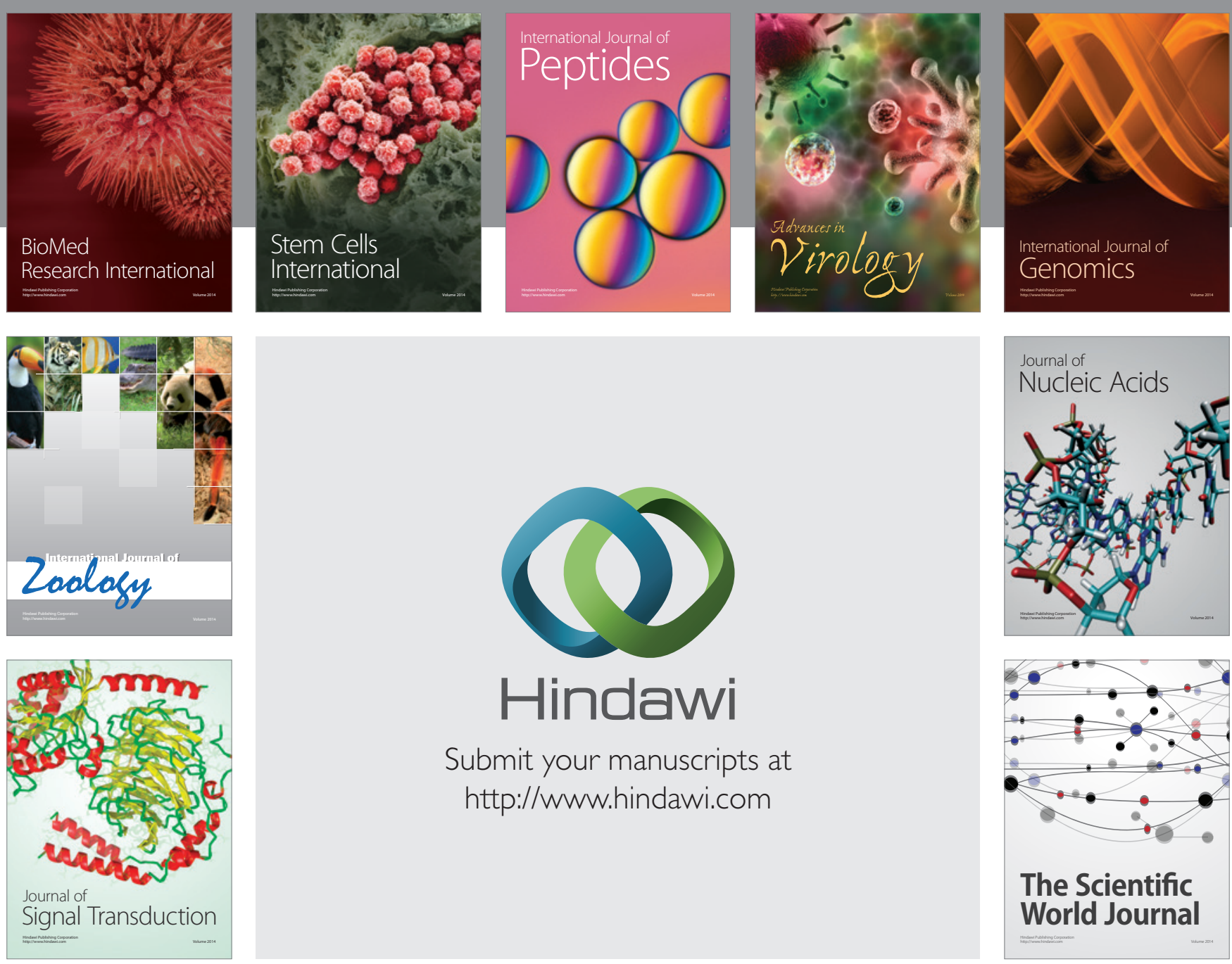

Submit your manuscripts at

http://www.hindawi.com
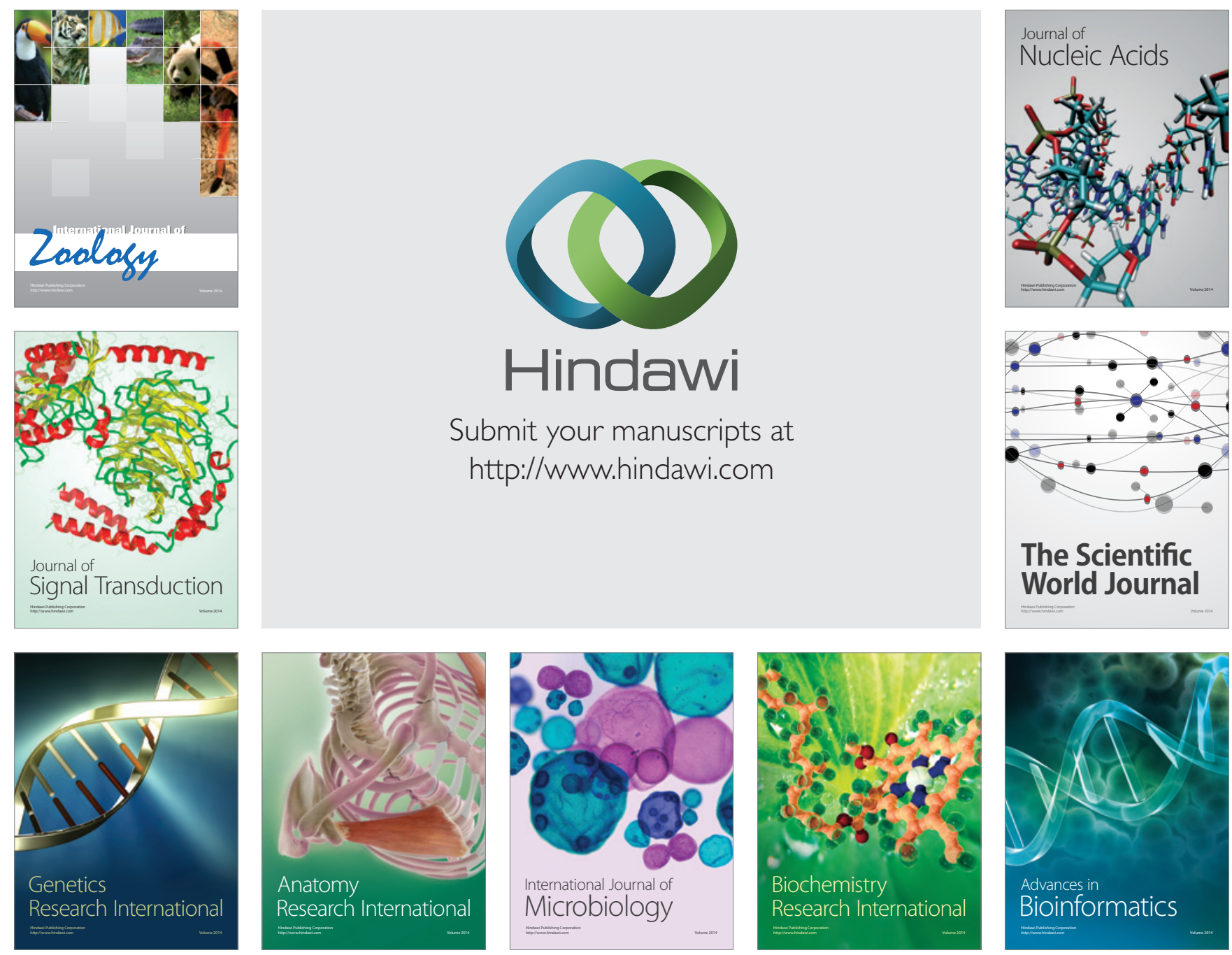

The Scientific World Journal
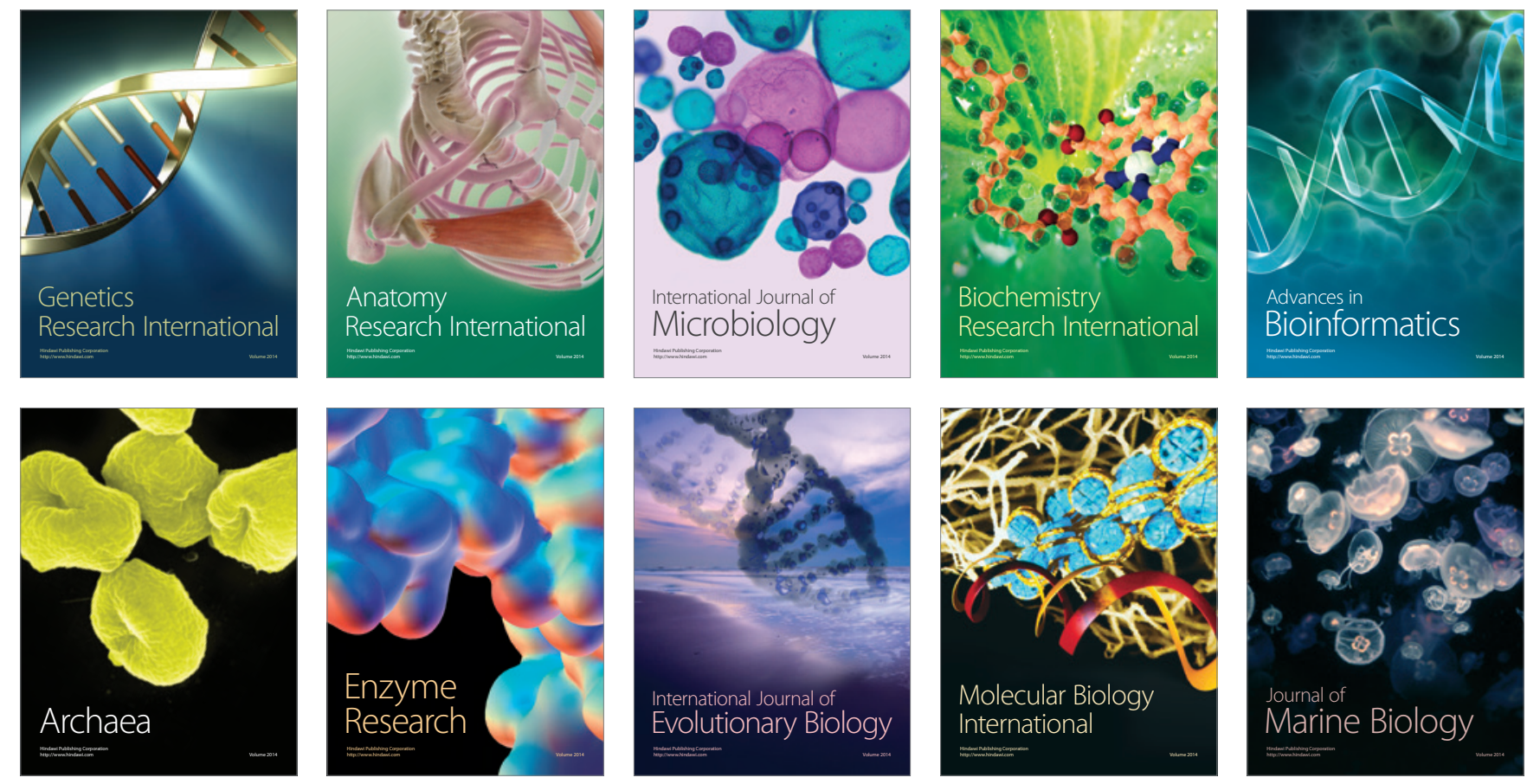